\title{
How Readers Construct New Testament Characters: The Calling of Peter in the Gospels in Cognitive- Narratological Perspective
}

\author{
Cornelis Bennema \\ London School of Theology, London, UK \\ University of the Free State, Bloemfontein, South Africa \\ cor.bennema@lst.ac.uk
}

\begin{abstract}
The discipline of cognitive narratology applies insights of cognitive linguistics to narrative analysis. This study seeks to demonstrate the value of cognitive narratology by exploring the role of the reader and the extent of the reader's knowledge in constructing characters. While traditional narrative criticism often limits itself to the world of the text, cognitive narratology recognizes that the reader's knowledge from other texts and the real world also contributes to the construction of characters. This study will show that the extent of the reader's literary and social knowledge of a text affects the construction of characters. As a case study, we will examine the calling of Peter in the canonical Gospels and show how four readers with varying degrees of knowledge will arrive at different constructions of Peter's character.
\end{abstract}

\section{Keywords}

character construction - cognitive narratology - gospels - narrative analysis - Peter - reader

\section{Introduction}

The sub-discipline of cognitive narratology applies insights of cognitive linguistics to narrative analysis. This study aims to show the value of cognitive narratology by focusing on one aspect: the reader's amount of knowledge in 
constructing characters. Ancient characterization is often indirect, so a reader must infer aspects of character from the sparse information in the text (and possibly beyond the text) through a method called "filling in the gaps." In narratology, there is considerable debate about the nature of the reader, what she or he knows and how she or he constructs character. ${ }^{1}$ While traditional narrative criticism tends to limit itself to the world of the text, cognitive narratology recognizes that the reader's knowledge from other texts and the real world also contributes to the construction of characters. ${ }^{2}$

This study will explore how the amount of knowledge available to a reader affects character constructions. Our strategy is to use multiple readers and assign them with various amounts of literary and social knowledge of the first-century Mediterranean world. ${ }^{3}$ Rather than providing a detailed theoretical argument, I shall test the proverbial saying, "the proof of the pudding is in the eating" (in this case, reading) and examine the calling of Peter in the canonical Gospels as a case study. By varying the number of texts the reader has access to and her or his awareness of socio-cultural schemata triggered by the text, we can ascertain how the reader's literary and social knowledge affects the construction of Peter's character.

I must explain the use of certain terms in this study. Adapting Uri Margolin's definition, "character" refers to a human or human-like actor, individual or

1 See S. Rimmon-Kenan, Narrative Fiction: Contemporary Poetics (London: Routledge, 2nd edn, 2002), pp. 118-130; R.M. Fowler, Let the Reader Understand: Reader-Response Criticism and the Gospel of Mark (Minneapolis: Fortress, 1991), pp. 25-40; J.L. Resseguie, Narrative Criticism of the New Testament: An Introduction (Grand Rapids: Baker Academic, 2005), pp. 30-33; several essays in J. Eder, F. Jannidis, and R. Schneider (eds.), Characters in Fictional Worlds: Understanding Imaginary Beings in Literature, Film and Other Media (Revisionen, 3; Berlin: De Gruyter, 2010), pp. 357-458; C. Bennema, A Theory of Character in New Testament Narrative (Minneapolis: Fortress, 2014), pp. 67-72. Ever since 2014, I have used the phrase "character reconstruction" for the reader's activity to distinguish it from the author's activity of "character construction" (the author creates a character and disperses information about that character in the text). In this study, however, I use "character construction" for the reader's activity to emphasize that the reader does not merely decode what the author has encoded. For a history of character construction in the Gospels since the 1980s, see Bennema, Theory of Character, 4-24 and the introductory essay in this Issue by Jan Rüggemeier and Elizabeth E. Shively.

2 See R. Schneider, "Toward a Cognitive Theory of Literary Character: The Dynamics of MentalModel Construction," Style 35 (2001), pp. 607-640; U. Margolin, "Character," in D. Herman (ed.), The Cambridge Companion to Narrative (Cambridge: Cambridge University Press, 2007), pp. 66-79. For a justification to apply modern literary approaches to ancient narratives, see Bennema, Theory of Character, pp. 53-56.

3 While the distinction between literary and social knowledge seems artificial because our knowledge of the first-century world comes mainly from literary sources (but also from archaeology and epigraphy), I distinguish between the reader's access to literary sources and the reader's general knowledge of the first-century world. 
collective, imaginary or real, who plays a role in the story of a narrative - in short, a story world participant. ${ }^{4}$ The term "narrative" denotes those literary works that contain a story and a storyteller, and can refer to both fiction and non-fiction. ${ }^{5}$ Finally, "reader" refers to a modern reader rather than a hypothetical first century reader or auditor, even though the modern reader may resemble one from the first-century. ${ }^{6}$

\section{The Construction of Reader and Character}

Cognitive narratology stresses the role of the reader. After all, without readers characters remain "dead" in the text; only when a text is read do characters come to life in the mind of the reader. In this section, we will address who the reader is and what the reader knows when constructing characters from the text.

\section{The Construction of the Reader}

Scholars have deployed various kinds of reader to analyze the text. ${ }^{7}$ Classic narratology and narrative criticism usually use the concept of implied reader, whose knowledge is essentially restricted by the world of the text because the implied reader itself is a construct of the text. ${ }^{8}$ Some use a "broader" implied

4 Margolin, "Character," p. 66. Classical narratology understands character more narrowly, either as a Greimassian functional actant subordinated to plot or a narrative participant defined mainly by traits, speech and actions. Uri Margolin, however, argues that his broader understanding of character as a "non-actual individual" is superior ("Individuals in Narrative Worlds: An Ontological Perspective," Poetics Today 11 [1990], pp. 843-871).

5 R. Scholes, J. Phelan and R. Kellogg, The Nature of Narrative (Oxford: Oxford University Press, 2nd edn, 2006), pp. 4, 283-285.

6 Based on insights from cognitive science, we learn that both ancient and modern readers use similar cognitive processes in encountering a text. See M. Whitenton, Hearing Kyriotic Sonship: A Cognitive and Rhetorical Approach to the Characterization of Mark's Jesus (BibInt Series, 148; Leiden: Brill, 2017), pp. 31-36; T. Smith, The Fourth Gospel and the Manufacture of Minds in Ancient Historiography, Biography, Romance, and Drama (BibInt Series, 173; Leiden: Brill 2019), p. 11; J. Rüggemeier, "Mark's Jesus Reviewed: Towards a Cognitive-Narratological Reading of Character Perspectives and Markan Christology," in G. van Oyen (ed.), Reading the Gospel of Mark in the Twenty-First Century: Method and Meaning (BetL, 3o1; Leuven: Peeters, 2019), pp. 717-735 (723). Our choice of a modern reader also circumvents the issue of firstcentury literacy and whether the term "auditor" is more appropriate in dealing with an ancient text.

7 For an informed discussion, see Fowler, Let the Reader Understand, pp. 25-40.

8 S. Chatman, Story and Discourse: Narrative Structure in Fiction and Film (London: Cornell University Press, 1978), pp. 146-151; W. Booth, The Rhetoric of Fiction (Chicago: University of Chicago Press, 2nd edn, 1983), pp. 428-431. 
reader, familiar with other texts when the text under consideration refers or alludes to them - the dynamic of intertextuality. ${ }^{9}$ James Resseguie presents a more "mature" form of narrative criticism, stating that the narrative critic should be familiar with the cultural, linguistic, social and historical assumptions of the audience envisioned by the implied author. Nevertheless, he still contends that this information must be obtained primarily from the text itself rather than from outside the text. ${ }^{10}$ Others use the concept of intended reader - the kind of reader that the real author might have had in mind when he wrote his narrative. However, it is debatable how much we can know of the real author and hence how accurately we can determine the intended reader. Perhaps it is better, then, to employ a contemporary reader who has access to all ancient sources. However, John Lyons warns that a modern reader's piecing together of a character from all available sources simply corresponds to what historians do. ${ }^{11}$ In our case, such a reading would result in a "historical" Peter rather than a Markan, Lukan or Johannine one.

Without seeking to list every possible kind of reader, it is clear that the choice of reader will affect the construction of characters. While this would seem obvious, only few scholars address this issue. John Darr is among the first to recognize that the reader one postulates determines at least in part how characters are constructed. ${ }^{12}$ On the one hand, Darr admits that literary critics likely create readers in their own image, that is, the reader is usually a heuristic construct of the modern critic. On the other hand, Darr also values the construction of a text-specific reader, that is, an approximation of the intended reader with a degree of knowledge of the socio-cultural conventions assumed by the original author. Darr's reader, then, is a heuristic hybrid, a fusion of

9 For example, A. Culpepper, Anatomy of the Fourth Gospel (Minneapolis: Fortress, 1983), pp. 212-224; E. Struthers Malbon, In the Company of Jesus: Characters in Mark's Gospel (Louisville: Westminster John Knox, 2000), pp. 9-10.

10 Resseguie, Narrative Criticism, pp. 32, 39. Resseguie adopts Iser's implied reader (for Iser, see below). Similarly, Elizabeth Struthers Malbon states that "narrative critics are wary of interpretations based on elements external to the narrative - including the intentions (known or supposed) of the real author" ("Narrative Criticism: How Does the Story Mean?," in J.C. Anderson and S.D. Moore (eds.), Mark and Method: New Approaches to Biblical Studies [Minneapolis: Fortress, 2nd edn, 2008], pp. 29-57 [28]).

11 W.J. Lyons, "Joseph of Arimathea: One of 'the Jews,' But with a Fearful Secret!," in S.A. Hunt, D.F. Tolmie and R. Zimmermann (eds.), Character Studies in the Fourth Gospel: Narrative Approaches to Seventy Figures in John (wUnT, 314; Tübingen: Mohr Siebeck, 2013), pp. 646657 (650).

12 J.A. Darr, "Narrator as Character: Mapping a Reader-Oriented Approach to Narration in Luke-Acts," Semeia 65 (1993), pp. 43-6o. Darr helpfully reminds us that while readers construct characters, critics construct readers ("Narrator as Character," p. 46). 
ancient and modern cultural horizons. ${ }^{13}$ In my work on character construction in New Testament narrative and in keeping with Darr's hybrid reader, I have used a "plausible historically informed modern reader," that is, a modern reader who has adequate social knowledge of the first-century world and can give a plausible explanation for the ancient sources she or he presumes. ${ }^{14}$

Fruitful as such discussion may be, scholars (including myself) are all on a quest for a single type of reader, who will produce a particular reading of the text. ${ }^{15}$ Very few have taken a different approach and shown that the reader's knowledge affects the construction of characters in the text. Robert Tannehill was probably the first to use different readers. He explored how two imaginary first-century persons might have heard the story of the Lukan Jesus, showing that the social location of each plays a crucial role in character construction. ${ }^{16}$ In a study on the Johannine character of Joseph of Arimathea, Lyons deploys two possible readings - one where the implied reader only has access to John's Gospel and another where the reader also knows Mark's Gospel. ${ }^{17}$ In a study on Jesus's mother in the canonical Gospels, I showed how each author portrayed Jesus's mother and how their portrayals differ. ${ }^{18}$ Although my focus was on the author, I implied four readers, who were familiar with (i) Mark; (ii) Mark and Matthew; (iii) Mark, Matthew and Luke; (iv) Mark and John, respectively. Nevertheless, I did not explicitly show how readers with access to different sources might construct the same character differently. Hence, in this study, we will employ multiple readers, with differing degrees of literary and social knowledge, to show the effect on the construction of character. Before we do, I will consider the reading process and the amount of knowledge we assign to our reader.

13 Darr, "Narrator as Character," pp. 47-48.

14 Bennema, Theory of Character, pp. 67-72. A modern reader becomes historically informed or gains adequate social knowledge of the first-century world through historical research, which requires an extratextual approach (see further below).

15 We must also remember that there are as many readers as there are actual readers because any reader is a heuristic construct of the real reader.

16 R.C. Tannehill, “'Cornelius' and 'Tabitha' Encounter Luke's Jesus," Interpretation 48 (1994), pp. 347-356.

17 Lyons, "Joseph of Arimathea," pp. 646-657.

18 C. Bennema, "Character Reconstruction in the New Testament (2): The Practice," ExpTim 127 (2016), pp. 417-429. See also A. Bedenbender, Frohe Botschaft am Abgrund: Das Markusevangelium und der Jüdische Krieg (SKI.NF, 5; Leipzig: Evangelische Verlagsanstalt, 2013), pp. 75-115, who discusses differently informed readers. 


\section{The Construction of Character}

The truism "there are no characters without a text" would imply that characters are limited to the world of the text and that the reader's construction of characters is based solely on the information in the text. Traditional narrative criticism would lean towards this view (see above). However, this is unrealistic because no text provides complete or exhaustive information, so readers naturally make inferences to fill the textual blanks. Wolfgang Iser showed a long time ago that the reading process involves a creative activity called "filling in the gaps," caused by the convergence of text and reader where the "unwritten" part of a text stimulates the reader's imagination. Iser notes that the text is inexhaustible since each reader will decide, individually, how to fill these gaps. ${ }^{19}$

Iser's reading dynamics readily apply to New Testament narrative where characterization is often indirect and readers must infer aspects of character from the sparse information in the text and construct character by "filling in the gaps. ${ }^{20}$ Frank Kermode asserts that in constructing character readers should augment the text "by inferring from the repertoire of indices characteristics not immediately signalled in the text, but familiar from other texts and from life." ${ }^{21}$ Darr builds on Kermode and is one of the earliest narrative critics who advocates an extratextual approach to character (which correlates to his "hybrid reader" earlier). ${ }^{22}$ Even if we recognize that readers (can) fill the

19 W. Iser, "The Reading Process: A Phenomenological Approach," New Literary History 3 (1972), pp. 279-299. See also Chatman, Story and Discourse, pp. 119-120; Rimmon-Kenan, Narrative Fiction, pp. 59, 128-130.

20 For the practice of leaving gaps in narratives to encourage audience participation as an ancient rhetorical tool, see K.R. Maxwell, Hearing Between the Lines: The Audience as FellowWorker in Luke-Acts and its Literary Milieu (LNTS, 425; London: T\&T Clark, 2010).

21 F. Kermode, The Genesis of Secrecy: On the Interpretation of Narrative (Cambridge: Harvard University Press, 1979), p. 78. Almost twenty years after Narrative Fiction was first published in 1983 , Rimmon-Kenan notes a development from a fairly unified classical narratology to a diversity of interdisciplinary postclassical narratologies, including a cultural-historical narratology that is contextual, historical and diachronous in orientation (Narrative Fiction, pp. 141-143).

22 Darr, "Narrator as Character," pp. 50-51. More comprehensively, see J.A. Darr, On Character Building: The Reader and the Rhetoric of Characterization in Luke-Acts (Louisville: Westminster John Knox, 1992), pp. 16-36. D.B. Gowler also uses extratextual information or cultural scripts to analyze the Lukan Pharisees (Host, Guest, Enemy and Friend: Portraits of the Pharisees in Luke and Acts [ESE C, 2; New York: Peter Lang, 1991], pp. 15-26). More recently, Maxwell asserts that "if information for filling gaps is not found within the narrative, the audience turns to its wider cultural context" and supplies knowledge of the world such as knowledge of other literature, social norms and rhetorical conventions (Hearing Between the Lines, p. 20). 
narrative gaps with knowledge of other literary sources and the real world, I suggest that we must apply hermeneutical controls in keeping with the genre conventions of the text we are reading and the world in which the text originated. The emerging sub-discipline of cognitive narratology develops these insights from literary criticism.

Cognitive narratology views character construction as a cognitive-psychological process where readers conceptualize "text-based mental models of possible individuals ... in the course of textual processing."23 More comprehensively, as Marcus Hartner states,

[t]he mental character model represents the conceptual "space" where incoming textual data, pre-stored knowledge structures, and readergenerated epistemic and emotional inferences of all sorts dynamically interact to form a (more or less) coherent and complete mental representation of a particular character. ${ }^{24}$

With direct characterization, the reader processes the textual information directly (e.g. he is a brave knight), but in the case of indirect characterization, the reader makes inferences about the character based on her or his general world knowledge (e.g., in a Western movie, the individual with a black hat and facial scar is the villain).$^{25}$ This raises an important issue for the construction of characters in New Testament narrative, where characterization is often indirect. If the reader's construction of character is not limited to textual information but includes text-based inferences related to the reader's general knowledge structures of the world, we must ask what knowledge structures of what world we are talking about. Schneider asserts,

[r]eaders from a later period than the text's origin will have to rely heavily on text-specific information unless they have acquired socio-historical knowledge that turns them into well-informed readers who are able to activate quasi-social categorizations quickly. ${ }^{26}$

23 Margolin, “Character," p. 76.

24 M. Hartner, "Constructing Literary Character and Perspective: An Approach from Psychology and Blending Theory," in R. Schneider and M. Hartner (eds.), Blending and the Study of Narrative: Approaches and Applications (Narratologia, 34; Berlin: De Gruyter, 2012), p. 90.

25 Margolin, "Character," pp. $76-78$. For a comprehensive treatment of the readers' use of their experience and knowledge of the world in the construction of characters as mental models, see Schneider, "Cognitive Theory," pp. 607-640 (to which Margolin refers); idem, "The Cognitive Theory of Character Reception: An Updated Proposal," Anglistik 24 (2013), pp. 117-134.

26 Schneider, “Cognitive Theory," pp. 620-621 (emphasis added). 
Adapting an assertion by Hartner for our study on Peter's calling, we could say,

[t]he activation of historical and literary knowledge, like genre expectations or behavioral conventions of [first-century Jewish society], are thus as important for processing the scene [at the Sea of Galilee] as the semantic decoding of the words on the page. ${ }^{27}$

Hence, the reader must acquire knowledge of the world in which the text originated.

An additional reason for considering information outside the text is that literary genre conventions should guide readers on how to fill in the textual gaps. Many scholars regard the narrative material of the New Testament as non-fictional and as having some referential relationship to real events and people in history. ${ }^{28}$ Hence, readers should go beyond the text when it concerns the construction of New Testament characters and fill the textual gaps from their knowledge of the socio-cultural context of the first-century Mediterranean world (rather than from unregulated imagination). This continuity between the narrative world and the "real" world does not imply a oneto-one correspondence between a New Testament character and the "real," historical person in all its aspects - New Testament authors had freedom in constructing characters. At the same time, reference to the "real" world also occurs for fictional narratives embedded in non-fictional narratives (e.g., parables). The parable of the "Good Samaritan," for example, must be understood by some reference to the "real" world, such as the nature of the relationship between Jews and Samaritans in the first century. Hence, the same cognitive processes apply for the construction of fictional and non-fictional characters. Nevertheless, I expect that readers will draw more on socio-cultural schemata of the real world for the character construction of Peter than that of the "Good Samaritan" for example. This is an important new direction in narrative analysis. Too often, classical narrative criticism restricts itself to the text of the Gospels and the narrative world these evoke, effectively reading the Gospels as fictional narratives disconnected from reality. In contrast, cognitive narratology also considers social schemata from the "real" world.

27 The original wording had "eighteenth century gentry" and "in Pemberley," respectively, with reference to Jane Austen's novel Pride and Prejudice (Hartner, "Constructing Literary Character," p. 9o).

28 See especially P. Merenlahti and R. Hakola, "Reconceiving Narrative Criticism," in D. Rhoads and K. Syreeni (eds.), Characterization in the Gospels: Reconceiving Narrative Criticism (JSNTS, 184; Sheffield: Sheffield Academic Press, 1999), pp. 4O-43. 
In sum, there are two related arguments for adopting an extratextual approach to constructing character. First, literary critics (e.g., Kermode, Rimmon-Kenan, Darr) have shown that even for fictional narrative the reader's construction of character draws on knowledge of the real world, ${ }^{29}$ and cognitive narratology has made this explicit (Schneider, Margolin)..$^{30}$ Second, the Gospels are non-fictional narratives, requiring us to take an extratextual approach to construct character from the text. This does risk readers bringing all kinds of extratextual assumptions and information to the text, so I suggest that, to keep hermeneutical control, readers fill in the textual gaps with literary and social knowledge of the first-century Mediterranean world to guide the construction of characters. In other words, while character is always a mental figure constructed by the reader, this process of character construction should be informed by knowledge of other texts and the "real" world in which the text originated..$^{31}$

\section{Constructions of Peter's Calling}

Peter's calling by Jesus occurs in all four canonical Gospels, but we will only examine the accounts in Mark, Luke and John because Matthew closely follows Mark (cf. Matt. 4:18-20 and Mark 1:16-18). As mentioned earlier, we will

29 See also F. Zipfel, Fiktion, Fiktivität, Fiktionalität: Analysen zur Fiktion in der Literatur und zum Fiktionsbegriff in der Literaturwissenschaft (Allgemeine Literaturwissenschaft - Wuppertaler Schriften, 2; Berlin: Schmidt, 2001), p. 82, who states, "Geschichten, die in keiner Relation zu unserer Wirklichkeitskonzeption stehen, könnten wir weder erzählen noch verstehen, wir könnten sie uns nicht einmal vorstellen."

30 New Testament scholars who embrace cognitive narratology include J. Rüggemeier, Poetik der markinischen Christologie: Eine kognitiv-narratologische Exegese (WUNT, 2/458; Tübingen: Mohr Siebeck, 2017), pp. 49-77; E.E. Shively, "Intentionality and Narrative Worldmaking in the Gospel of Mark: Rethinking Narrative Communication," in G. van Oyen (ed.), Reading the Gospel of Mark in the Twenty-First Century: Method and Meaning (B ETL, 301; Leuven: Peeters, 2019), pp. 343-394 (365-376); M.R. Whitenton, Configuring Nicodemus: An Interdisciplinary Approach to Complex Characterization (LNTS, 549; New York: Bloomsbury T\&T Clark, 2019), pp. 11-54.

31 In their introductory essay in this Issue, Jan Rüggemeier and Elizabeth Shively mention specific categories of literal and social knowledge, such as mental models of persons and cultural frames and scripts. Another aspect of hermeneutical control in the construction of characters is public discourse. As Margolin explains, characters "exist" not only as an object of thought in the individual reader's imagination but also as an object of discourse in public consultation. When actual readers share and compare their individual text-based mental images of a particular character, usually a public notion of the character emerges that does not depend on any one reader (Margolin, "Character," p. 67). 
use multiple readers, who each have a distinct amount of literary knowledge, and show how this leads to different constructions of Peter's character. ${ }^{32}$ We will also consider the potential effect on Peter's character construction if we were to boost the reader's social knowledge of the first-century Mediterranean world. The main purpose is not to adjudicate between the different readings and constructions but to show how the reader's literary and social knowledge affects the construction of Peter's character.

\section{Reader 1: Constructing "Peter" from Mark 1}

In terms of literary knowledge, Reader 1 knows Mark as well as the Old Testament (to which the Markan narrative often alludes). Mark 1:1-15 is bookended by the

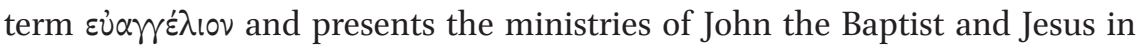

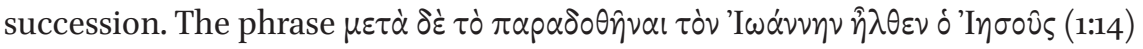
marks a sharp discontinuity, indicating that Jesus starts his ministry only after John has left the scene. At the same time, 1:14-15 are also transitional verses, introducing the start of Jesus's ministry in 1:16-45. Jesus's first acts see him appointing apprentices with identical calls to two sets of brothers - Simon and Andrew, and James and John. Mark 1:16-18 parallels 1:19-20 in that (i) Jesus spots two brothers and invites them to follow him; (ii) each pair immediately responds in an identical manner. Our focus is on the calling of Simon in Mark 1.

In terms of family, the reader learns that Simon has a brother Andrew (1:16), is married (1:30), and lives with his brother, mother-in-law and possibly other family members in Capernaum (1:29-30). Simon is a fisherman, probably on the lower end of the social scale because, unlike the Zebedee brothers, there is no mention of Simon and his brother having a boat or hired workers. ${ }^{33}$ From the sparse interaction between Jesus and Simon in 1:16-18, the reader notes that Jesus takes the initiative (he sees and speaks), while Simon responds (he abandons his profession and follows Jesus). Jesus catches (pun intended) Simon in the act of fishing and challenges him to become his apprentice and a fisher of people. Simon does not speak but acts - impulsively it seems because

32 Once we discount Matthew as a distinct source for Peter's calling, there are seven possible readers, but to keep the study feasible, we will only regard readers who know (i) Mark; (ii) Mark and Luke; (iii) John; (iv) Mark, Luke and John, and disregard readers who know (v) Luke; (vi) Mark and John; (vii) Luke and John.

33 According to cognitive linguistics, readers pay more attention to character traits that stand in contrast to those of other characters (S. Finnern and J. Rüggemeier, Methoden der neutestamentlichen Exegese: Ein Lehr- und Arbeitsbuch [utb, 4212; Tübingen: A. Francke Verlag, 2016], pp. 203-205). 
he immediately ( $\varepsilon \dot{\theta} \theta \dot{\varsigma} \varsigma$ ) leaves his net and follows Jesus (1:18). Since Simon does not speak, the reader does not know how Simon understood Jesus's enigmatic offer of a new profession ( $\gamma \varepsilon v \varepsilon \dot{\varepsilon} \sigma \theta \alpha \iota \dot{\alpha} \lambda \iota \varepsilon \dot{\varsigma} \varsigma \alpha \dot{\alpha} \theta \rho \dot{\omega} \pi \omega \nu)$. The Old Testament uses the analogy of fishing in the context of judgment (Jer. 16:16; Ezek. 29:4-6; 38:4; Amos 4:2; Hab. 1:14-17), which may suggest that Simon will rescue people from eschatological judgment. ${ }^{34}$ The Markan text, however, does not provide clues if Simon made this connection. The reader may wonder why Simon did not question Jesus because it is odd to abandon one's livelihood and family abruptly to follow a stranger with a perplexing challenge. Unless, of course, Simon knows Jesus or has met him before - but the lack of information in the Markan narrative does not allow for such speculation.

In sum, the reader encounters huge gaps in the text - more like a "narrative crater." In constructing Simon's character, the reader can see that Simon is impulsive and willing to take risks, even to the point of appearing naïve. The reader is surprised by Simon's radical abandonment of trade and family in this brief encounter with Jesus. ${ }^{35}$ Suggestions that Simon had encountered Jesus prior to 1:16-18 or knew about Jesus by postulating a chronological gap between 1:14-15 and 1:16 are too speculative. Besides, Jesus's fame only spread after Simon's calling (1:28). Consequently, the reader's mental picture of Simon's character is very limited. We will now explore how this changes when we boost our reader's social knowledge.

\section{The Reader's Enhanced Comprehension with Social Knowledge}

Social knowledge of first-century Mediterranean culture will enable the reader to situate Simon's calling in a broader context, thus providing a "thick" reading. From ancient rhetorical handbooks, for example, the reader can learn

34 B. Witherington, The Gospel of Mark: A Socio-Rhetorical Commentary (Grand Rapids: Eerdmans, 2001), pp. 85-86; S.W. Henderson, Christology and Discipleship in the Gospel of Mark (sntsms, 135; Cambridge: Cambridge University Press, 2006), pp. 6o-62; M. Bockmuehl, Simon Peter in Scripture and Memory: The New Testament Apostle in the Early Church (Grand Rapids: Baker Academic, 2012), p. 23. Unlike Simon, the reader may have understood the metaphor of catching people as participation in Jesus's mission of proclaiming the gospel, exorcising demons and healing the sick $(3: 14-15 ; 6: 12-13 ; 13: 10)$ and calling people to follow Jesus (W. Taylor Shiner, Follow Me! Disciples in Markan Rhetoric [SBLDS, 145; Atlanta: Scholars Press, 1995], pp. 175-176; J. Marcus, Mark 1-8 [AnB, 27; New York: Doubleday, 200o], pp. 184-185).

35 Although the reader will note that Simon still attends to his ill mother-in-law in 1:29-31, it is important to understand that Simon's action in 1:18 is nevertheless a radical leaving of family and trade because later in the narrative Simon rephrases his "leaving the nets" ( $\dot{\varphi} \varphi \dot{v} v \varepsilon \varsigma \tau \dot{\alpha}$

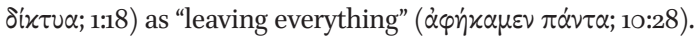


that family and livelihood are important topoi ${ }^{36}$ The basic unit of first-century society was the household or extended family - the nucleus (parents and children), the families of married children, slaves, family friends - headed up by the paterfamilias. ${ }^{37}$ Simon's father is possibly the paterfamilias (the father of James and John is still alive [1:20]). In terms of Simon's livelihood, the Sea of Galilee was known to teem with fish and being a fisherman could be lucrative. ${ }^{38}$ Nevertheless, while the Zebedee family has a small fishing business, Simon and Andrew catch fish from the shore, so from a socio-economic perspective, they probably belong to the lower middle stratum of society. ${ }^{39}$ The reader will also know that the core values in ancient Mediterranean culture were honour and shame. Honour refers to worth, reputation or social status that is publicly acknowledged; it is primarily a group value and individual members of a group share in its honour. In this collectivist honour-shame society, the reader will perceive Simon's radical decision to abandon trade and family as dishonourable and irresponsible because it transcends a private decision with personal consequences and places the burden of providing for the extended family on others. The reader may wonder whether Simon was also struck by the unusual situation because while Jewish rabbis and their disciples continued to practise a trade, Jesus challenges Simon to abandon it. ${ }^{40}$

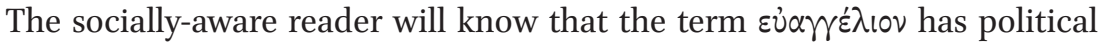
overtones, for example the announcement of the birth of an emperor or an

36 For ancient lists of rhetorical topoi, see G.A. Kennedy (trans.), Progymnasmata: Greek Textbooks of Prose Composition and Rhetoric (Leiden: Brill, 2003). In contrast, cognitive narratology tends to analyze character in antiquity in modern categories (see, e.g., Rüggemeier, "Mark's Jesus," pp. 723-724). Whitenton's cognitive approach, however, is more aware of ancient schemata (Nicodemus, pp. 47-53).

37 B.J. Malina, The New Testament World: Insights from Cultural Anthropology (Louisville: Westminster John Knox, 3rd edn, 2001), pp. 58-67.

38 Witherington, Gospel of Mark, p. 84.

39 See also L.W. Hurtado, Mark (NIBC, 2; Peabody: Hendrickson, 1989), p. 25; S. Freyne, "The Fisherman from Bethsaida," in H.K. Bond and L.W. Hurtado (eds.), Peter in Early Christianity (Grand Rapids: Eerdmans, 2015), pp. 19-29. For the socio-economic stratification of firstcentury Palestinian society, see K.C. Hanson and D.E. Oakman, Palestine in the Time of Jesus (Minneapolis: Fortress, 1998), p. 117.

40 See R.H. Gundry, Mark: A Commentary on His Apology for the Cross (Grand Rapids: Eerdmans, 1993), p. 67. Besides, the rabbinical tradition has no call stories (M. Hengel, The Charismatic Leader and His Followers [trans. J.C.G. Greig; Edinburgh: T\&T Clark, 1981], pp. $5^{0-51)}$. Others claim that the Markan call stories (1:16-18, 19-20; 2:12-14) resemble those in the Greek philosophical traditions (Shiner, Follow Me, pp. 172-198) or a biblical call story where a divinely-appointed messenger summons someone to share his mission, like Elijah calling Elisha (S.C. Barton, Discipleship and Family Ties in Mark and Matthew [snTsms, 80; Cambridge: Cambridge University Press, 1994], p. 61). However, we cannot assume that Simon made these connections. 
emperor's ascent to the throne. Hence, Jesus's status as Messiah and Son of God (1:1) and his programme of good news about God's imminent kingdom (1:14-15) is diametrically opposed to the agenda of Rome and its Empire (including its client king Herod). Besides, the mention of John attracting a large audience from Judaea and Jerusalem (1:5) and his subsequent arrest (1:14) will have alerted the reader that John's message and activity had a religious-political dimension (see also 6:17-29). The reader will understand Jesus's ministry to be an actualization of John's programme, thus extending its religious-political dimension. The reader is surprised, however, that Jesus launches his campaign in his Galilean backyard rather than Judaea with Jerusalem as the religiouspolitical capital. If Simon did understand the religious-political dimension of Jesus's programme when Jesus called him (and this remains speculative), the reader would evaluate Simon's impulsive decision to leave trade and family to be less naïve and more radical and bold. ${ }^{41}$

The reader must also consider how Simon understood his new "profession" as "a fisherman of people" ( $\dot{\alpha} \lambda \varepsilon \varepsilon \dot{\alpha} \varsigma \dot{\alpha} \nu \theta \rho \omega \dot{\omega} \pi \omega \nu)$. Drawing on cognitive linguistics, the reader will recognize that $\dot{\alpha} \lambda \varepsilon \varepsilon \hat{\varsigma} \varsigma \dot{\alpha} \nu \theta \rho \omega \dot{\omega} \pi \nu$ constitutes conceptual blending, where a conceptual metaphor creates a blended mental image through a mapping of two domains. ${ }^{42}$ In this case, Jesus merges two conceptual domains - the source domain "fisherman" gets mapped onto the target domain "people" - to create a new metaphor "to catch people." As Seana Coulson explains, "because [conceptual] blending relies on people's imaginative capacities, it often results in novel concepts and can be used to adapt cultural models to the rhetorical goals of individual members of the culture." ${ }^{33}$ Simon may have understood Jesus's metaphor as a call to recruit people for some new association, but what did he think the "bait" to catch people would be? If he recognized the religious-political aspect of Jesus's programme, he might have understood Jesus's call as joining a kind of Jewish holy war against the Romans. ${ }^{44}$ Although

41 K.M. Hartvigsen is overconfident in claiming that "audience members will infer that these two brothers [Simon and Andrew] agree to Jesus' plan and commit themselves to it" (Prepare the Way of the Lord: Towards a Cognitive Poetic Analysis of Audience Involvement with Characters and Events in the Markan World [BzNw, 180; Berlin: De Gruyter, 2012], p. 129).

42 See D. Geeraerts, "Introduction: A Rough Guide to Cognitive Linguistics," in D. Geeraerts (ed.), Cognitive Linguistics: Basic Readings (Berlin: Mouton De Gruyter, 2006), p. 14.

43 S. Coulson, "Conceptual Blending in Thought, Rhetoric, and Ideology," in G. Kristiansen, M. Achard, R. Dirven, and F.J. Ruiz de Mendoza Ibáñez (eds.), Cognitive Linguistics: Current Applications and Future Perspectives (Applications of Cognitive Linguistics, 1; Berlin: Mouton De Gruyter, 2008), p. 187.

44 Marcus notes some parallels with the call of a revolutionary leader in Jewish traditions (Mark 1-8, pp. 183-184). 
such reading is speculative, it would drastically change the construction of Simon's character from being naïve to being courageous and radical.

In sum, based on the amount and kind of social knowledge we assign to the reader, Simon could understand Jesus's words in multiple ways, ranging from an innocent invitation to a different fishing programme to a recruitment call to join a hazardous revolutionary programme. The contrasting ends of this spectrum shows how the extent of a reader's social knowledge affects the construction of Simon's character.

\section{Reader 2: Constructing Peter from Mark 1 and Luke 5}

Reader 2 knows Luke, Mark and the Old Testament, and we will focus on how the reader's increased literary knowledge affects the construction of Simon Peter's calling. The reader of Luke 4-5 will note several differences with the account in Mark 1. First, in Luke the healing of Simon's mother-in-law (4:38-39) occurs prior to Simon's calling (5:1-11), whereas Mark has these in reverse order $(1: 16-18,29-31)$. Second, while Mark has recorded the calling of Simon, Andrew, James and John with no particular focus on any (1:16-20), Luke singles out the calling of Simon and significantly enhances the Markan account (5:1-11). Third, in Luke, Simon owns a boat and is in business with the Zebedee family $(5: 3,10)$, while Mark makes no mention of this. Fourth, while Mark informs the reader that Simon is named "Peter" only after his calling (3:6), in Luke this happens during the event of Simon's calling (5:8). Important for our study is to consider how Reader 2 constructs Peter's character differently from Reader 1 based on this knowledge.

The significance of Luke reordering Mark's accounts of Peter's calling and the healing of his mother-in-law is that in Luke, Peter knows Jesus prior to his call. Like Mark, Luke reveals that Peter lives in Capernaum (4:31, 38). In Mark, Jesus visits Capernaum after calling Peter (1:21), so the reader cannot assume that Peter knows Jesus prior to 1:16. In Luke, however, Jesus has visited both the synagogue and Peter's house in Capernaum (4:31-39) before he calls Peter in $5: 1-11$, so the reader is aware that Peter knows Jesus prior to his calling. In fact, there might have been various points of contact. First, 4:23 implies that Jesus had performed miracles in Capernaum prior to the accounts in 4:31-37, so Peter may have heard about or even witnessed these. Second, 4:38 informs the reader that after leaving the synagogue Jesus went straight to Peter's house. It is unlikely that Jesus entered Peter's house uninvited; instead, Jesus was probably informed in the synagogue that Peter's mother-in-law was ill (perhaps by Peter himself). Jesus's willingness to go along and heal Peter's mother-in-law would 
have left a lasting impression on Peter. Peter would also have been aware of further healings and exorcisms Jesus performed on that day (4:35, 40-41; Jesus only leaves Capernaum in 4:42). This knowledge and experience would have consolidated Jesus's reputation as a miracle worker for Peter. So, when it comes to the account of the calling of Peter in 5:1-11, the reader is acutely aware that Peter has already encountered Jesus and knows a lot about him.

We saw earlier that considerable gaps in the Markan account of Peter's calling leave the reader to conjecture when constructing Peter's character. Perhaps familiar with Mark's sparse description and having access to more sources (1:1-4), Luke significantly enhances the Markan account. This allows Reader 2 to construct Peter's character differently from Reader 1. First, Luke mentions that Jesus notices two boats $(5: 2)$. One boat belonged to Peter $(5: 3)$ (and his brother Andrew, as implied by the plurals in 5:5-6), and the other boat belonged to Peter's business partners James and John of Zebedee (5:7, 10). This information puts Peter on the same footing as the Zebedee brothers. With it, Luke elevates Peter's socio-economic status from an independent fisherman with little means to a partner in a medium-size fishing business. Second, Luke describes a longer encounter between Jesus and Peter in 5:4-8. The reader notes that Peter is willing to obey Jesus's unusual proposition to fish in daytime, resulting in a miraculous catch of fish that threatens to sink both boats. Peter's response, "Go away from me, Lord, for I am a sinful man" $(5: 8)$ is puzzling but the reader may see a connection with 5:32, where Jesus states that the purpose of his coming is to call sinners. ${ }^{45}$ While Peter, aware of his inadequacy, seeks to distance himself from Jesus, it is Jesus's purpose to call and associate with people like Peter. Peter's reaction suggests an understanding of Jesus as a divine agent: his nonverbal prostration and verbal address "Lord" is indicative of "religious behaviour before the divine," mirroring the responses of prophets like Moses and Isaiah when they experienced a theophany, with Jesus's reply, "Do not be afraid," echoing the divine response. ${ }^{46}$ Third, while the Markan Jesus plucks Peter out of his profession with the promise to make him a fisher of people (1:17), the Lukan Jesus provides Peter with an object lesson

45 Classic narratology might claim that a reader cannot know information that is further on the text continuum, and hence could not have made the connection with 5:30-32. However, this is naïve because it would only apply to a first reading; in any subsequent reading, the reader will notice this connection.

46 F. Bovon, Luke 1: A Commentary on the Gospel of Luke 1:1-9:50 (Hermeneia; Minneapolis: Fortress, 2002), p. 17o. See also M. Wolter, The Gospel According to Luke: Volume 1 (Luke 1-9:50) (trans. W. Coppins and C. Heilig; Waco; Baylor University Press, 2016), pp. 226-227. 
- a miraculous catch of fish - to help Peter visualize the nature and magnitude of his new vocation to catch people (5:10). ${ }^{47}$ Luke also underlines the magnitude of Peter's decision to follow Jesus, from leaving his nets (Mark 1:18) to leaving everything $(\pi \dot{\alpha} \nu \tau \alpha ; 5: 11) .{ }^{48}$

The overall effect is that Luke has significantly reduced the gaps in the Markan account, thus enhancing Peter's characterization and providing a stronger rationale for Peter radically abandoning everything to follow Jesus. ${ }^{49}$

\section{The Reader's Enhanced Comprehension with Social Knowledge}

Luke's setting for Peter's calling is virtually identical to Mark's (Jesus calls Peter as he is fishing on the shores of the Sea of Galilee after which Peter radically abandons trade and family to follow Jesus), ${ }^{50}$ so the informed Lukan reader has much the same social knowledge as the Markan reader. However, Peter has knowledge of Jesus as a miracle worker in Luke, so he may have viewed his encounter with Jesus against the Old Testament tradition of a prophetic call, like Elisha being called by Elijah. In which case, though it remains speculative, Peter's abrupt renunciation of family and occupational ties would be an act of obedience and submission..$^{51}$ Though it is unclear whether the Markan Peter would have understood the revolutionary potential of Jesus's programme (see Reader 1), there is more scope that Luke's Peter did because while in Mark Jesus's fame spread after Peter's calling (1:28), in Luke this happens the other way around (4:14). The additional social knowledge the reader can acquire from the infancy narratives in Luke 1-2 and Luke's expansion of Mark 1:1-13 in 3:1-4:13 does not significantly enhance or modify the construction of Peter's character, so we turn to our next reader.

47 Ernest Best notes that fish die when they are caught but in Luke the "catch" stays alive

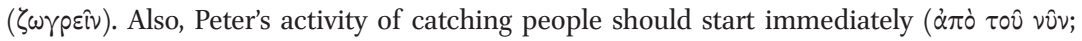
5:10), while Mark places it in the future ( $\pi \circ \eta \dot{\sigma} \sigma \omega ; 1: 17)$ (Following Jesus: Discipleship in the Gospel of Mark [JsnTs, 4; Sheffield: Jsot Press, 1981], p. 170).

48 In Mark, this is emphasized only in 10:28 (see n. 35 above).

49 Shiner notes that ancient call stories always provide motivation for following, so Luke probably found the lack of motivation in the Markan call stories problematic and provided a rationale for Peter's acceptance of Jesus's call (Follow Me, pp. 183-184).

50 The only difference is that Jesus's use of Peter's boat as a pulpit to address the crowd is part of Luke's setting of Peter's calling $(5: 3)$, while in Mark this is the setting for Jesus's teaching in parables (4:1).

$5^{1}$ While I rejected this suggestion from Barton for Mark (see n. 40, above), his idea has validity in Luke. 


\section{Reader 3: Constructing Peter from John 1}

In this section, we encounter a reader who only knows the Johannine narrative (and the Old Testament). After the encounter between John and Jesus (1:2934), the remainder of John 1 recounts how Jesus gathers his first disciples in two parallel sections (1:35-42 and 1:43-51). One of Jesus's first disciples is Simon and the reader notes that the information about him is sparse. Simon is from the town of Bethsaida (1:44), on the shores of the Sea of Galilee, but there is no mention of his profession. ${ }^{2}$ He has a brother Andrew and their father is called "John" (1:40, 42). Beyond this terse description, the reader notes that Simon is entirely passive in 1:40-42 - he is found and brought to Jesus by his brother and does not utter a word.

The reader is puzzled by Simon's inaction on two occasions. First, Simon does not show any emotion when his brother announces that he has encountered the Messiah (1:41). The reader knows from 1:35-40 that Andrew was a disciple of John (the Baptist) and very likely had witnessed Jesus's implied baptism by John (1:29-34). Hence, Andrew would have understood Jesus to be the Lamb who was going to take away the sin of the world (1:29, 36), learned more about Jesus during his stay with him (1:37-40), and concluded that Jesus is the expected Messiah (1:41). The reader will infer that Andrew is excited by his discovery of Israel's long-awaited messiah and eager to tell his brother. There is no evidence that Simon was part of John the Baptist's circle, so Andrew would have rushed back to Bethsaida to inform his brother and take him down to Perea. It is astonishing that Simon does not react to hearing this astounding revelation.

The second event is Simon's encounter with Jesus, when Jesus looks at him intently and informs him of his new name "Peter" (1:42). To provide a little social knowledge, a change of name was a significant event in antiquity (especially when God bestowed the new name) because the name usually reflected (aspects of) the person's character, ${ }^{53}$ and signified intimacy and privilege. ${ }^{54}$ The Greek "Peter" and its Aramaic equivalent "Cephas" play on the word "(bed) rock" in Greek ( $\pi \dot{\tau} \tau p \alpha)$ and Aramaic (kepha). Once again, Simon shows no reaction. The reader notes that Jesus uses a future tense in announcing Simon's

52 The reader will infer much later that Peter was a fisherman (21:2-3). Bethsaida means "house of fishing" or "fisherman's house," but John 1 provides no clue that Peter was a fisherman.

53 L. R. Helyer, The Life and Witness of Peter (Downers Grove: IVP Academic, 2012), pp. 20-21.

54 M.H. Williams, "From Shimon to Petros: Petrine Nomenclature in the Light of Contemporary Onomastic Practices," in H.K. Bond and L.W. Hurtado (eds.), Peter in Early Christianity (Grand Rapids: Eerdmans, 2015), pp. 39-40. 
new name and wonders when Simon will live up to it. Reading on, the reader discovers that Simon is nothing like "the Rock"; rather, he is depicted as unstable and showing conflicting traits $(13: 6-10,36-38 ; 18: 10-27 ; 21: 20-22) .{ }^{55}$

In sum, the reader is baffled by Peter's passivity in John 1 - he does not act or speak. Jesus's revelatory insight into Peter's life does not elicit a faithconfession from him, unlike Andrew, Philip and Nathanael, who all profess something about Jesus's identity $(1: 41,45,49) .{ }^{56}$

\section{The Reader's Enhanced Comprehension with Social Knowledge}

We must now consider whether boosting the reader's social knowledge will affect the construction of Peter. The reader assumes that Peter knows that Andrew was part of the Baptist movement and that Andrew must have said more to Peter than just the words "we have found the Messiah." So, the reader infers that Peter may have acquired certain knowledge about Jesus via Andrew, such as Jesus being the Lamb of God who removes sin, the Spirit-baptizer and a rabbi. Assuming that Andrew shared this knowledge with Peter, it is astonishing that Peter remains impassive. The reader's social knowledge about these categories, therefore, does not enhance the construction of Peter's character but only complicates it because Peter's utter passivity in light of this potential knowledge is staggering.

\section{Reader 4: Constructing Peter from Mark 1, Luke 5 and John 1}

The last reader we deploy has literary knowledge of Mark, Luke and John; in other words, Reader 4 has the combined knowledge of Readers 1-3. This reader notes several discrepancies between the accounts in Mark-Luke and John regarding Peter's calling. Some can be readily explained. For example, the Johannine Peter is linked to Bethsaida, while the Synoptic Peter resides in Capernaum. A likely scenario is that Peter grew up in Bethsaida - the phrase $\dot{\varepsilon} x$ $\tau \eta \hat{\varsigma} \pi^{\prime} \lambda \varepsilon \omega \varsigma$ (1:44) probably denotes origin - and relocated to Capernaum later. ${ }^{57}$ Other discrepancies, however, are perplexing. First, the setting or circumstances of Peter's calling is very different. In Mark-Luke, Jesus meets Peter and

55 While Peter acquires a leading role among the disciples (6:68-69; 20:2; 21:3), the reader does not consider his high status in the group to match the designation "Rock" because he remains unstable throughout the Johannine narrative. Only at the end of the Johannine narrative, the reader will learn how Simon will become "the Rock" (21:15-19).

$5^{6}$ Peter's confession is delayed until 6:68-69, where he speaks for the Twelve.

57 See also Bockmuehl, Simon Peter, pp. 22-23. 
Andrew while they are fishing at the Sea of Galilee; in John, Peter is brought from Galilee to Perea by Andrew to meet Jesus, and only then does Jesus go to Galilee (1:43). Second, in Mark-Luke, Peter responds to Jesus's call by leaving everything and following him; in John, Peter is not shown to leave anything and his following of Jesus is assumed rather than stated. Third, in Mark, Peter's calling (1:16-18) occurs after the arrest of John the Baptist (1:14), while in John, Peter's calling (1:41-42) occurs before John's arrest (3:24). This incongruity between Mark-Luke and John demands an explanation. While the reader can place the Markan Peter and Lukan Peter on the same characterization spectrum, it would be impossible to situate the Johannine Peter on it. Forced to think of an alternative scenario, the reader might infer that there were two callings, where Peter's calling in John occurred prior to his calling in Mark-Luke. We must explore this scenario.

The Johannine narrative contains information that Peter's calling occurred before John (the Baptist) was arrested. First, 1:35-42 reveals that John introduced Andrew to Jesus and that, at once, Andrew set off to find Peter and introduce him to Jesus. Second, 3:22-30 shows that John was still baptizing. The aside in 3:24 that "John, of course, had not yet been thrown into prison" is odd and only makes sense to an audience that may have thought otherwise - a Markan audience, for example! John 3:22-30 is part of what scholars have recognized as a broader literary unit, recounting Jesus's journey "from Cana to Cana" (2:1-4:54). ${ }^{58}$ The implication is that the events described in John 1 and John 2-3 occurred before John was arrested, and the events in John 4 happened soon after John's arrest, if the latter is implied in 4:1-3. In other words, John 1-4 provides an extended peek into the earliest phase of Jesus's ministry, and fits best between Mark 1:13 and 1:14. ${ }^{59}$

In sum, Peter's calling in John 1 occurs prior to his calling in Mark 1 and Luke 5. The reader can now see why Peter leaves everything in Mark-Luke but

$5^{8}$ Within John 2-4, only 2:13-22 is displaced in that John, for theological reasons, brings forward an incident that Mark and Luke place at the end of Jesus's ministry. Even so, the reader is meant to understand that in the Johannine narrative world the events in John 1-4 happened prior to the Baptist's arrest.

59 In Luke, the place of insertion is more complicated to discern because while the best place seems between 4:13 and 4:14, John's imprisonment is already mentioned in 3:20, before Jesus's baptism in 3:21-22. Others have noted similar interlocking relationships between John and Mark: for example, R. Bauckham, "John for Readers of Mark," in R. Bauckham (ed.), The Gospels for All Christians: Rethinking the Gospel Audiences (Grand Rapids: Eerdmans, 1998), pp. 147-171; P.N. Anderson, "John and Mark: The Bi-Optic Gospels," in R.T. Fortna and T. Thatcher (eds.), Jesus in Johannine Tradition (Louisville: Westminster John Knox, 20o1), pp. 175-188. An alternative explanation is that John corrected rather than supplemented the 
nothing in John. In John 1, Jesus has not called Peter to follow him and hence there is no need to leave trade and family. Peter's implied presence in John 2-4, as part of the recurrent term oi $\mu \alpha \theta \eta \tau \alpha$, would suggest that he was on a short excursion with Jesus. When we come to Mark 1 and Luke 5 , Jesus explicitly calls Peter to follow him and he responds by abandoning everything. This more permanent calling of Peter in Mark-Luke can then be placed somewhere between John 4 and 6 (no disciples are mentioned in John 5). To mention an example of boosting the reader's social knowledge, in Jewish and Graeco-Roman antiquity pupils sought to associate themselves with a teacher. Reader 4 notes that John's account reflects this practice $(1: 37-39,42)$ but in Mark-Luke Jesus takes the initiative, calling Peter to associate with him. ${ }^{60}$ Hence, early in Jesus's ministry, Peter associates himself with Jesus, ${ }^{61}$ and later, Jesus seeks out Peter to become his apprentice.

\section{Conclusion}

This study has argued that the extent of the reader's literary and social knowledge of a text affects the construction of its characters. ${ }^{62}$ We have demonstrated this in a case study on the calling of Peter in the canonical Gospels where we used four readers. The differing levels of literary knowledge of each reader led to different constructions of Peter's character. A reader with access to Mark alone, will find big gaps in the text because without any explanation Peter leaves his trade and family to join Jesus. A reader who knows Mark and Luke will note that Luke has expanded the Markan narrative, reduced the textual gaps and enhanced Peter's characterization, thus providing a narrative rationale for Peter's leaving trade and family. A reader who only knows John encounters a passive, silent Peter with no explicit ties to fishing, does not leave anything and makes no confession. A reader who knows Mark, Luke

Markan account and considered his account as the only accurate one. However, the text does not hint at this and I contend that our reconstruction best explains the data.

6o In John 1, Jesus arguably does not call any of his disciples (he only extends an invitation in 1:39) and potential disciples seem to take the initiative. When Jesus says in John 6:70; 15:16 that he has taken the initiative, this very likely refers to the later calling of the disciples in the Synoptics.

61 To be more precise, Peter is passive in John 1:41-42 and it is Andrew who introduces him to Jesus.

62 For a comprehensive model of how readers can construct characters, see Bennema, Theory of Character or, briefer, C. Bennema, Reconstructing Characters in the Gospels (Grove Biblical Series B99; Cambridge: Grove Books, 2021). 
and John will note that Peter's characterization in Mark and Luke is at odds with that in John and may infer that these divergent characterizations point to different traditions - a calling of Peter early on in Jesus's ministry (John), followed by another calling later on (Synoptics). We have also seen the effect social knowledge has on the construction of Peter's character by exploring the reader's knowledge of socio-cultural schemata such as (i) vocational "calling" and recruiting apprentices; (ii) abandoning trade and family in a collective, honour-shame culture; and (iii) the religious-political dimension of Jesus's programme.

The use of multiple readers and narratives raises the issue of "character migration," where a character (re)appears in several narrative worlds. So, we must consider whether Peter has remained the same across narrative worlds or undergone a metamorphosis. When moving from the Markan to the Lukan narrative world, the reader meets the same Peter but enhanced. In both narrative worlds, Peter is a fisherman at work along the shore of the Sea of Galilee, who leaves trade and family to follow Jesus and "catch people." While Luke has significantly enhanced Peter's characterization, in essence he is the same Peter. A reader who subsequently engages with the Johannine narrative world may initially think this is a different Peter. The Johannine Peter is no fisherman (at least not in John 1), does not meet Jesus in Galilee and receives no call to become a fisher of people; instead, he is told that he will be "the Rock." On reflection, however, the reader will realize that the Johannine and MarkanLukan narrative worlds present the same Peter but on different occasions, in which the migration of Peter's character from John to Mark to Luke is a gradual unfolding of the same character rather than an evolutionary transmutation from one character into another.

We stated early on that we would not adjudicate between possible readings but simply show that the extent of information available to the reader affects the construction of literary characters. In a sense, all four readings are legitimate within the knowledge structures assigned to each. Whether any reading is more appropriate or historically more plausible must be determined by other criteria and considerations. The implication of this study is that interpreters should be more cognizant of their constructed reader because this will influence the construction of characters. Nevertheless, there are differences in quality across the various constructions. For example, compared to Reader 1, Reader 2 arrives at an enhanced construction of Peter's character. Or one could argue that Reader 4 operates with an enhanced data set compared to Reader 3 because the Johannine text seems to assume the reader's knowledge of Mark. In fact, Reader 4 arrives at the most sophisticated understanding of Peter's character because only this reader can know that Peter's calling happened in 
two stages over an extended time. Following Peter's two-stage calling, Reader 4 notes a progression in Peter's characterization from being "passive" in John 1 to "little active" in Mark 1 to "very active" in Luke 5.

\section{Acknowledgement}

I thank Elizabeth Shively, Jan Rüggemeier and the anonymous reviewer for their constructive comments on earlier drafts. 